\title{
Genistein improves viability, proliferation and mitochondrial function of cardiomyoblasts cultured in physiologic and peroxidative conditions
}

\author{
SERENA FARRUGGIO ${ }^{1}$, GIULIA RAINA ${ }^{1}$, GRAZIA COCOMAZZI ${ }^{1}$, CARLOTTA LIBRASI $^{1}$, \\ DAVID MARY $^{1}$, SERGIO GENTILLI ${ }^{2}$ and ELENA GROSSINI ${ }^{1}$
}

${ }^{1}$ Laboratory of Physiology and Experimental Surgery, Department of Translational Medicine, AGING Project,
University of East Piedmont; ${ }^{2}$ General Surgery Unit, Department of Health of Sciences,
University of East Piedmont; University Hospital Company Major of Charity, I-28100 Novara, Italy

Received March 22, 2019; Accepted August 2, 2019

DOI: $10.3892 /$ ijmm.2019.4365

\begin{abstract}
Phytoestrogens exert protective effects on the cardiovascular system through mechanisms that have yet to be clearly demonstrated. The aim of this study was to evaluate the protective effects exerted by genistein on cardiomyoblasts (H9C2) against oxidative stress, nitric oxide (NO) release, viability, proliferation/migration and mitochondrial function. $\mathrm{H} 9 \mathrm{C} 2$ cultured in physiological or peroxidative conditions, were treated with genistein in the absence or presence of estrogen receptors (ERs), G protein-coupled-estrogenic-receptors (GPER), Akt, extracellular-signal-regulated kinases 1/2 (ERK1/2) and p38 mitogen activated protein kinase (p38MAPK) blockers. Cell viability, proliferation, migration, mitochondrial membrane potential, mitochondrial oxygen consumption and oxidant/antioxidant system, were measured by specific assays. Western blot assay was used for the analysis of NO synthase (NOS) subtypes' and expression and activation of various kinases. In
\end{abstract}

Correspondence to: Professor Elena Grossini, Laboratory of Physiology and Experimental Surgery, Department of Translational Medicine, AGING Project, University of East Piedmont, via Solaroli 17, I-28100 Novara, Italy

E-mail: elena.grossini@med.uniupo.it

Abbreviations: DCF, 2,7-dichlorodihydrofluorescein; DMEM, Dulbecco's modified Eagle's medium; eNOS, endothelial NOS; ERK1/2, extracellular-signal-regulated kinases 1/2; ERs, estrogen receptors; FBS, fetal bovine serum; GPER, G protein-coupledestrogenic-receptors; H2DCFDA, 2,7-dichlorodihydrofluorescein diacetate; iNOS, inducible NOS; L-NAME, N $\omega$-nitro-L-arginine methylester; MTT, 1\% 3-[4,5-dimethylthiazol-2-yl]-2,5-diphenyl tetrazolium bromide; NO, nitric oxide; NOS, nitric oxide synthase; PBS, phosphate-buffered saline; p38MAPK, p38 mitogen activated protein kinase; ROS, reactive oxygen species; JC-1, 5,51,6,61-tetrachloro-1,11,3,31 tetraethylbenzimidazolyl carbocyanine iodide

Key words: cell survival, estrogens, nitric oxide, mitochondria function, phytoestrogens all experiments $17 \beta$-estradiol was used for comparison. The results showed that phytoestrogens and estrogens can increase cell viability, proliferation/migration and improve mitochondrial membrane potential and oxygen consumption of $\mathrm{H} 9 \mathrm{C} 2$. Furthermore, NO release was modulated by genistein and $17 \beta$-estradiol. These effects were reduced or abolished by the pre-treatment with ERs, GPER, Akt, ERK1/2 and p38MAPK blockers. Finally, a reduction of reactive oxygen species production and an increase of glutathione content was found in response to the two agents. In $\mathrm{H} 9 \mathrm{C} 2$ cultured in physiological conditions, genistein induced endothelial NOS-dependent NO production through the involvement of estrogenic receptors and by the modulation of intracellular signalling related to Akt, ERK1/2, and p38MAPK. Moreover, estrogens and phytoestrogens protected $\mathrm{H} 9 \mathrm{C} 2$ against oxidative stress by reducing inducible NOS expression and through the modulation of the antioxidant system and mitochondrial functioning.

\section{Introduction}

It is widely accepted that oxidative stress may represent one characteristic feature in the pathological progress of cardiac damage by affecting DNA, lipids and proteins, in addition to activating a redox-regulated signalling cascade that ultimately leads to cell death (1). Since mitochondria are the main target of reactive oxygen species (ROS) production and damage (2), the modulation of mitochondrial dysfunction could assume clinical relevance in the prevention of heart disease.

Nitric oxide (NO) has been reported to play either a beneficial or harmful role in the control of cardiovascular system, depending on the dose and duration of exposure (3). On the one hand, the blocking of NO production via endothelial NO synthase (eNOS) would abolish the cardioprotection against ischemia/reperfusion injury (4). On the other hand, inducible NOS (iNOS)-dependent NO production could be detrimental for cardiac function $(5,6)$ through augmented formation of peroxinitrites.

Thus, the modulation of mitochondria activity and NO release could represent a therapeutic tool for the management of cardiac disease. Genistein, the main soy-derived isoflavone 
with a multitude of health benefits (7), has been reported to exert protective effects on the cardiovascular system through its antioxidant and anti-inflammatory function (8), which would be related to both mitochondria and NO. Hence, in human aortic and porcine coronary endothelial cells, genistein enhanced eNOS expression and augmented NO synthesis (9-11). In addition, the opposite effects of genistein on iNOS/eNOS-related NO release were found to be associated with its beneficial role against isoproterenol-induced cardiac hypertrophy (12). It is also notable that in different cell types, genistein was able to counteract the damage caused by peroxidation by preserving mitochondrial function $(13,14)$. Mechanisms related to extracellular signal-regulated kinases $1 / 2$ (ERK1/2), mitogen-activated protein kinase (MAPK) and Akt intracellular pathways have been reported to be involved in the above effects (15).

Although there is extensive literature about the cardiovascular effects elicited by genistein, data concerning its function on cardiac cells remain scarce. Thus, in this study we examined the effects of genistein on cardiomyoblast viability, proliferation/migration and mitochondrial function in both physiological and peroxidative conditions and analyzed the involvement of eNOS/iNOS-dependent NO release and ERK1/2, p38MAPK and Akt pathways. Since genistein has gained clinical consideration for the management of postmenopausal symptoms, due to its molecular structure that resembles that of estrogens, its effects were compared with those elicited by $17 \beta$-estradiol.

\section{Materials and methods}

Culture of $\mathrm{H} 9 \mathrm{C} 2$. Rat cardiomyoblasts (H9C2) were obtained from the American Type Culture Collection (ATCC; cat. no. CRL-1446) and cultured in Dulbecco's modified Eagle's medium (DMEM; Sigma-Aldrich) supplemented with $10 \%$ fetal bovine serum (FBS; Euroclone), $2 \mathrm{mM}$ L-glutamine (Sigma-Aldrich) and $1 \%$ penicillin-streptomycin (SigmaAldrich) at $37^{\circ} \mathrm{C}$ with $5 \% \mathrm{CO}_{2}$ in an incubator. For $\mathrm{NO}$ measurement, 7,500 cells/well were plated in 96-well plates with DMEM 0\% FBS supplemented with $1 \%$ penicillin-streptomycin-glutamine and without phenol red (starvation medium, Sigma-Aldrich) for 4-6 h. Mitochondrial membrane potential and cell viability were also measured, following the same procedure used for NO measurement, but with plating of $1 \times 10^{4}$ cells/well. For ROS quantification, $2.5 \times 10^{4}$ cells/well were plated in 96-wells. For Trypan Blue test and western blot analysis, $4 \times 10^{5}$ cells/well were plated in 6-well plates in complete medium, and at $80 \%$ confluency at least, they were incubated with starvation medium overnight. Each experimental protocol was repeated in five different cell samples.

$N O$ release. The NO production was measured in $\mathrm{H} 9 \mathrm{C} 2$ culture supernatants using the Griess method (Promega; cat. no. G2930) as previously performed in the same or similar cellular models (16-20). H9C2 cardiomyoblasts were treated for $30 \mathrm{~min}$ with genistein $(10 \mathrm{pM}, 100 \mathrm{pM}, 10 \mathrm{nM}$, $100 \mathrm{nM}$ and $1 \mu \mathrm{M}$; Sigma-Aldrich; cat. no. G6649) and $17 \beta$-estradiol (10 pM, $100 \mathrm{pM}, 10 \mathrm{nM}, 100 \mathrm{nM}$ and $1 \mu \mathrm{M}$; Sigma-Aldrich; cat. no. E8875). In addition, some samples were stimulated with the NOS blocker, $\mathrm{N} \omega$-nitro-L-arginine methylester (L-NAME; $10 \mathrm{mM}$; Sigma-Aldrich), the p38 MAPK inhibitor, SB203580 (100 nM; Sigma-Aldrich), the phosphatidylinositol 3'-kinase (PI3K) inhibitor, wortmannin (100 nM; Sigma-Aldrich), the MAPK/ERK inhibitor, UO126 (100 nM; Sigma-Aldrich), the associated estrogen receptors (ERs) inhibitor, fulvestrant (100 nM; Sigma-Aldrich), and the $\mathrm{G}$ protein-coupled estrogenic receptors (GPER) inhibitor, G15 (100 nM; Sigma-Aldrich), which were administered for $30 \mathrm{~min}$ prior to genistein $(100 \mathrm{nM})$ and $17 \beta$-estradiol $(100 \mathrm{nM})$. Those inhibitors were also administered alone at the above reported concentrations, to $\mathrm{H} 9 \mathrm{C} 2$ for $30 \mathrm{~min}$. In addition, in some experiments the effects of genistein and $17 \beta$-estradiol were examined in peroxidative conditions obtained by using hydrogen peroxide. In particular, $200 \mu \mathrm{M}$ hydrogen peroxide was administered for $30 \mathrm{~min}$ after the $30 \mathrm{~min}$-pretreatment of $\mathrm{H} 9 \mathrm{C} 2$ with genistein $(100 \mathrm{nM})$ and $17 \beta$-estradiol $(100 \mathrm{nM})$ and the effects on $\mathrm{NO}$ release were examined. At the end of the stimulations, NO production in the sample's supernatants was examined by adding an equal volume of Griess reagent following the manufacturer's instructions. At the end of incubation, absorbance at $570 \mathrm{~nm}$ was measured by a spectrometer (VICTOR $^{\text {TM }}$ X Multilabel Plate Reader; PerkinElmer) and the role of NO production in this step was examined. The value of each sample was quantified in respect to nitrite standard curve and expressed as nitrite production $(\mu \mathrm{M})$.

Cell viability. Oxidative stress was generated in $\mathrm{H} 9 \mathrm{C} 2$ through $200 \mu \mathrm{M}$ hydrogen peroxide for $30 \mathrm{~min}$ in starvation medium. Cell viability was examined using the $1 \% 3$-[4,5-dimethylthiazol-2-yl]-2,5-diphenyl tetrazolium bromide (MTT; Life Technologies Italia; cat. no. CT02) dye, as previously described (16-20). H9C2 cardiomyoblasts were treated in physiological and peroxidative conditions with genistein (10 pM, $100 \mathrm{pM}, 10 \mathrm{nM}, 100 \mathrm{nM}$ and $1 \mu \mathrm{M}$, for $30 \mathrm{~min}$; SigmaAldrich) and 17 $\beta$-estradiol (10 pM, 100 pM, $10 \mathrm{nM}, 100 \mathrm{nM}$ and $1 \mu \mathrm{M}$, for $30 \mathrm{~min}$; Sigma-Aldrich), in the presence or absence of the same inhibitors used in Griess assay. The same experimental protocol described for NO release, with regard to estrogen/phytoestrogens alone or in the presence/absence of inhibitors in physiologic and peroxidative conditions, was followed. After each treatment, the medium was removed, and fresh culture medium without red phenol and FBS and with MTT dye was added in 96-well plates containing the cells and incubated for $2 \mathrm{~h}$ at $37^{\circ} \mathrm{C}$. Thereafter, the fresh culture medium without red phenol and FBS was removed, and an MTT solubilization solution (dimethyl sulfoxide; DMSO; Sigma-Aldrich) in equal volume to the original culture medium was added and mixed in a gyratory shaker until the complete dissolution of formazan crystals. Cell viability was determined by measuring the absorbance through a spectrometer (VICTOR ${ }^{\mathrm{TM}}$ X Multilabel Plate Reader; PerkinElmer) with a wavelength of $570 \mathrm{~nm}$ and cell viability was calculated by setting control cells as $100 \%$.

Mitochondrial membrane potential measurement. Mitochondrial membrane potential measurement in $\mathrm{H} 9 \mathrm{C} 2$ was performed with JC-1 assay. Cells were stimulated as described for cell viability. After stimulations, the medium of cells plated in starvation medium was removed and incubated with 5,51,6,61-tetrachloro-1,11,3,31 tetraethylbenzimidazolyl 
carbocyanine iodide (JC-1) 1X diluted in 1X Assay Buffer for $15 \mathrm{~min}$ at $37^{\circ} \mathrm{C}$ in an incubator, following the manufacturer's instructions (Cayman Chemical; cat. no. 10009172) and as previously performed $(13,16,18)$. After incubation, the cells were washed twice with $1 \mathrm{X}$ Assay Buffer and then the mitochondrial membrane potential was determined by measuring the red (excitation $550 \mathrm{~nm} / \mathrm{emission} 600 \mathrm{~nm}$ ) and green (excitation $485 \mathrm{~nm} / \mathrm{emission} 535 \mathrm{~nm}$ ) fluorescence through a spectrometer (VICTOR $^{\mathrm{TM}}$ X Multilabel Plate Reader; PerkinElmer). To identify cells undergoing apoptosis, the ratio of fluorescent intensity of J-aggregates to fluorescent intensity of monomers was used as an indicator of cell health.

Wound-healing migration assay. Cell migration was evaluated by the in vitro scratch assay in serum-starved cells. Briefly, cell monolayers were mechanically scratched with a sterile yellow tip (diameter $=2 \mathrm{~mm}$ ) along the center of the plate and cell debris was removed by gentle washing with PBS. Some samples were treated with genistein $(10 \mathrm{pM}, 100 \mathrm{nM})$ and $17 \beta$-estradiol $(10 \mathrm{pM}, 100 \mathrm{nM})$ for $24 \mathrm{~h}$ and $48 \mathrm{~h}$. Images of cell monolayers were taken using an optical microscope (Leica ICC50HD) with a digital camera to evaluate wound closure. Migration was quantified by calculating the area of wound at time points T0 (time of wound), T24 (24 h after wound) and $\mathrm{T} 48$ (48 $\mathrm{h}$ after wound) by using ImageJ software (National Institutes of Health). For each condition, the percentage of wound closure at several time points throughout the course of the assay, was obtained through the formula: \% wound closure: $\left[\mathrm{WA}_{0}-\mathrm{WA} / \mathrm{WA}_{0}\right] * 100$, where WA is the wound area and $\mathrm{WA}_{0}$ is the original size of the wound area. Experiments were conducted in triplicate and repeated at least five times.

Trypan blue proliferation assay. Cell proliferation was evaluated with Trypan blue exclusion method. Cells were stimulated as described for cell viability and mitochondrial membrane potential but with $24 \mathrm{~h}$ of stimulation and without blockers. At the end of the stimulation, the cells were detached and $50 \mu 1$ cell suspension was diluted 1:2 with Trypan blue and mixed by pipetting up and down and then, $10 \mu \mathrm{l}$ was put in the Burker chamber for cell counting. Blue cells were the non-viable cells.

The percentage of viable cells was calculated by dividing the number of viable cells by the number of total cells and multiplying by $100 \%$.

Glutathione (GSH) quantification. GSH measurement was performed with a specific kit (Cayman Chemical; cat. no. 703002$)$ as previously described $(13,16,20)$. H9C2 cardiomyoblasts were treated in peroxidative conditions with genistein $(10 \mathrm{pM}, 100 \mathrm{nM})$ and $17 \beta$-estradiol $(10 \mathrm{pM}, 100 \mathrm{nM})$ for $30 \mathrm{~min}$, in the presence of $200 \mu \mathrm{M}$ hydrogen peroxide. The antioxidant $200 \mu \mathrm{M}$ N acetyl-cysteine (NAC; Sigma-Aldrich), administered for $30 \mathrm{~min}$, was used as the positive control. After treatments, the cells were lysed using the $50 \mathrm{mM}$ 2-(N-morpholino) ethanesulphonic acid (GSH MES Buffer) and a rubber policeman. The cell pellet was centrifuged at $10,000 \mathrm{x} \mathrm{g}$ for $15 \mathrm{~min}$ at $4^{\circ} \mathrm{C}$. After centrifugation, the supernatant was treated with an equal volume of metaphosphoric acid (final concentration 5\%; Sigma-Aldrich) for $5 \mathrm{~min}$ and centrifuged at $2,000 \mathrm{x}$ g for at $\geq 2 \mathrm{~min}$. The supernatant was collected and supplemented with $50 \mu \mathrm{l}$ per $\mathrm{ml}$ of $4 \mathrm{M}$ solution of triethanolamine (Sigma-Aldrich). Then, $50 \mu 1$ of the samples was transferred to a 96-well plate where GSH was detected following the manufacturer's instructions through a spectrometer (VICTOR ${ }^{\mathrm{TM}}$ X Multilabel Plate Reader; PerkinElmer) at excitation/emission wavelengths of 405-414 nM. GSH was expressed as nanomoles in samples with $1.5 \mathrm{mg}$ of protein $/ \mathrm{ml}$.

ROS quantification. The oxidation of 2,7-dichlorodihydrofluorescein diacetate (H2DCFDA) into 2,7-dichlorodihydrofluorescein (DCF) was used to assess ROS generation, following the manufacturer's instructions (Abcam; cat. no. ab113851). Briefly, the cells in 96-well plates were stimulated with $30 \mathrm{~min} 200 \mu \mathrm{M}$ hydrogen peroxide alone or in the presence of genistein $(10 \mathrm{pM}, 100 \mathrm{pM}, 10 \mathrm{nM}, 100 \mathrm{nM}$ and $1 \mu \mathrm{M}$; for $30 \mathrm{~min})$ and $17 \beta$-estradiol $(10 \mathrm{pM}, 100 \mathrm{pM}, 10 \mathrm{nM}$, $100 \mathrm{nM}$ and $1 \mu \mathrm{M}$; for $30 \mathrm{~min}$ ). The antioxidant $200 \mu \mathrm{M}$ NAC was used as the positive control. After treatments, the reactions were stopped by removing the medium and washing with phosphate-buffered saline (PBS) followed by staining with $10 \mu \mathrm{M}$ $\mathrm{H} 2 \mathrm{DCFDA}$ for $20 \mathrm{~min}$ at $37^{\circ} \mathrm{C}$. The fluorescence intensity of DCF was measured at an excitation and emission wavelength of 485 and $530 \mathrm{~nm}$ by using a spectrophotometer (VICTOR ${ }^{\mathrm{TM}}$ X Multilabel Plate Reader; PerkinElmer) $(13,16,18)$.

Oxygen consumption rate (OCR) assay. Oxygen consumption rate assay kit (MitoXpress-Xtra HS Method) (Cayman Chemical; cat. no. 600800) was used to assess the OCR, which is considered a parameter to study mitochondrial function. Briefly, cells in the 96-well plates were stimulated with $30 \mathrm{~min}$ $200 \mu \mathrm{M}$ hydrogen peroxide alone or in the presence of genistein $(10 \mathrm{pM}$ and $100 \mathrm{nM}$; for $30 \mathrm{~min}$ ) and $17 \beta$-estradiol $(10 \mathrm{pM}$ and $100 \mathrm{nM}$; for $30 \mathrm{~min})$. At the end of stimulation, $10 \mu \mathrm{M}$ of the probe (MitoXpress-Xtra Solution) was added in each well. The plate was read at $380 \mathrm{~nm}$ with a spectrophotometer $\left(\mathrm{VICTOR}^{\mathrm{TM}}\right.$ X Multilabel Plate Reader; PerkinElmer). The results correspond to the lifetime of the probe expressed in $\mu \mathrm{s}$, calculated using the formula: Lifetime $(\mu \mathrm{s})$ : (70-30)/ln (W1/W2) in which W1 and W2 represent window 1 and 2, respectively, for the measured intensity readings at each time point; 70 and 30 represent the delay time of $\mathrm{W} 1$ and $\mathrm{W} 2$.

Cell cycle analysis, by using propidium iodide stain. Flow cytometry was used for cell cycle analysis. This technique is widely used for measuring all phases of cell cycle including apoptosis (21). H9C2 cells ( 400,000 cells/well in 6-well plate), were stimulated with genistein (10 pM and $100 \mathrm{nM}$; for $24 \mathrm{~h})$ and $17 \beta$-estradiol (10 pM and $100 \mathrm{nM}$; for $24 \mathrm{~h}$ ) alone, or in the presence of $200 \mu \mathrm{M}$ hydrogen peroxide. The effects of $200 \mu \mathrm{M}$ hydrogen peroxide for $30 \mathrm{~min}$ alone were also examined. At the end of each stimulation, the culture medium was collected from each well and transferred in a $15 \mathrm{ml}$ tube in order to collect the cells that eventually detached. Cells were detached with trypsin-EDTA thereafter, an appropriate volume of culture medium was added, and cell suspension was transferred to a tube and centrifuged at $900 \mathrm{xg}$ for $5 \mathrm{~min}$ at room temperature. The supernatant was discarded, and cells were fixed in $1 \mathrm{ml}$ $70 \%$ ethanol for $1 \mathrm{~h} \mathrm{at}-20^{\circ} \mathrm{C}$. After $1 \mathrm{~h}$, the cells were centrifuged at $900 \mathrm{x} \mathrm{g}$ for $5 \mathrm{~min}$ at room temperature, and ethanol as well as the supernatant were discarded. Cells were washed with PBS and centrifuged again $900 \mathrm{x}$ g for $5 \mathrm{~min}$ at room 
temperature. Each pellet of cells was resuspended in $200 \mu 1$ propidium iodide buffer $(3.4 \mathrm{mM}$ trisodium citrate, $9.65 \mathrm{mM}$ sodium chloride, $0.003 \%$ tergitol), $25 \mu \mathrm{l}$ RNase A (10 ng/ml; Cabru), and $10 \mu \mathrm{l}$ propidium iodide ( $1 \mathrm{mg} / \mathrm{ml}$; Cabru).

Then, $50 \mu 1$ of each sample was transferred in a 96 -well plate in triplicate, and after $15 \mathrm{~min}$ at $37^{\circ} \mathrm{C}$ in the dark, the analysis was performed using Attune NxT (Life Technologies).

Cell lysates. The $\mathrm{H} 9 \mathrm{C} 2$ at confluence were plated in starvation medium overnight at $37^{\circ} \mathrm{C}$ with $5 \% \mathrm{CO}_{2}$. Western blot analysis was performed in $\mathrm{H} 9 \mathrm{C} 2$ treated with genistein $(10 \mathrm{pM}$ and $100 \mathrm{nM}$ for $30 \mathrm{~min})$ and $17 \beta$-estradiol $(10 \mathrm{pM}$ and $100 \mathrm{nM}$ for $30 \mathrm{~min}$ ) in the presence or absence of specific inhibitors, as described previously, for NO release and cell viability. In some samples, the effects of $200 \mu \mathrm{M}$ hydrogen peroxide, administered for $30 \mathrm{~min}$ after the $30 \mathrm{~min}$-pretreatment with $100 \mathrm{nM}$ phytoestrogens/estrogens, were also examined. Some samples of $200 \mu \mathrm{M}$ hydrogen peroxide were administered $30 \mathrm{~min}$ after phytoestrogens/estrogens. At the end of stimulation, H9C2 cardiomyoblasts were lysed in iced Ripa buffer supplemented with sodium orthovanadate (2 $\mathrm{mM}$; Sigma-Aldrich) and protease inhibitors cocktail (1 mM; Thermo Fisher Scientific) and phenylmethanesulfonyl fluoride ( $1 \mathrm{mM}$; Sigma-Aldrich). The extracted proteins were quantified through bicinchoninic acid protein (BCA; Pierce) and used for electrophoresis and immunoblotting studies.

Western blot analysis. Cell lysates $(30 \mu \mathrm{g}$ protein each sample) were dissolved in $5 \mathrm{X}$ Laemmli buffer, boiled for $5 \mathrm{~min}$ and resolved in $10 \%$ sodium dodecyl sulfate polyacrylamide gel electrophoresis gels (Bio-Rad Laboratories). After electrophoresis they were transferred to polyvinylidene fluoride membranes (Bio-Rad Laboratories), which were incubated overnight at $4^{\circ} \mathrm{C}$ with specific primary antibodies: Anti phospho-eNOS (1:1,000; Ser1177, Cell Signaling Technologies; cat. no. 9570), anti eNOS (1:1,000; Cell Signaling Technologies, cat. no. 32027), anti iNOS (1:500; Santa Cruz Biotechnology, cat. no. sc-7271), anti phospho-Akt (1:1,000; Ser473, Santa Cruz Biotechnology, cat. no. sc-33437), anti Akt (1:1,000; Santa Cruz Biotechnology, cat. no. sc-81434), anti phospho-ERK1/2 (1:1,000; Thr202/Tyr204, Santa Cruz Biotechnology, cat. no. sc-16982), anti ERK1/2 (1:1,000; Cell Signaling Technologies, cat. no. 9102), anti phospho-p38 MAP Kinase $(1: 1,000$; Thr180/Tyr182, Cell Signaling Technologies, cat. no. 9211), and anti p38 MAP Kinase (1:1,000; Cell Signaling Technologies, cat. no. 9212). The membranes were washed and then incubated with horseradish peroxidase-coupled goat anti-rabbit IgG (Sigma-Aldrich), peroxidase-coupled rabbit anti-goat $\mathrm{IgG}$ and horseradish peroxidase-coupled goat anti-mouse IgG (Sigma-Aldrich) for $45 \mathrm{~min}$ and were developed through a non-radioactive method using Western Lightning Chemiluminescence (PerkinElmer Life and Analytical Sciences). Phosphorylated protein expression was calculated as a ratio towards specific total protein expression or $\beta$-actin (1:5,000; Santa Cruz Biotechnology; cat. no. sc-47778) detection.

Statistical analysis. All data were recorded using the Institution's database. Statistical analysis was performed using STATVIEW version 5.0.1 for Microsoft Windows (SAS Institute Inc.) and GraphPad Prism 6 (San Diego). Data were checked for normality prior to statistical analysis. All the results obtained were examined through one-way ANOVA followed by Tukey's test, by comparing preselected pairs of column means. Pearson's coefficient was calculated for linear correlation analysis in dose-response studies. Data are presented as means \pm standard deviation (SD) of five independent experiments for each experimental protocol. $\mathrm{P}<0.05$ was considered statistically significant.

\section{Results}

Effects of genistein and $17 \beta$-estradiol on cell viability, proliferation/migration and mitochondrial membrane potential in the presencelabsence of various inhibitors. As shown in Fig. 1A, in physiological conditions genistein and $17 \beta$-estradiol increased cell viability in a dose-dependent manner up to $100 \mathrm{nM}$. At all doses genistein and $17 \beta$-estradiol improved the mitochondrial membrane potential (Fig. 1C). Furthermore, genistein and $17 \beta$-estradiol counteracted the effects of $200 \mu \mathrm{M}$ hydrogen peroxide on cell viability (Fig. 1B) and mitochondrial membrane potential (Fig. 1D). Moreover, both agents were able to increase cell proliferation in physiological (Fig. 2A) and peroxidative (Fig. 2B) conditions and increased cell migration (Fig. 2C and Fig. S1) up to $24 \mathrm{~h}$ from the beginning of the stimulation. The above effects were partly confirmed by the cell cycle analysis. Thus, in physiological conditions, genistein increased the percentage of H9C2 in G0/G1, S and G2/M phase (Figs. 3A and S2A). As regarding estradiol, both $10 \mathrm{pM}$ and $100 \mathrm{nM}$ were able to improve G0/G1 and $\mathrm{G} 2 / \mathrm{M}$ phases (Figs. 3A and S2A). In the peroxidative conditions, both genistein and $17 \beta$-estradiol reduced apoptosis at all doses. In comparison with hydrogen peroxide, $100 \mathrm{pM}$ and $100 \mathrm{nM}$ genistein and $10 \mathrm{pM}$ and $100 \mathrm{nM}$ estradiol were able to increase the percentage of $\mathrm{H} 9 \mathrm{C} 2$ in G0/G1. Doses of genistein and $17 \beta$-estradiol increased the percentage of $\mathrm{H} 9 \mathrm{C} 2$ in $\mathrm{S}$ and $\mathrm{G} 2 / \mathrm{M}$ phase, as well (Figs. 3B and S2B).

Of note is that, the effects of genistein and $17 \beta$-estradiol on cell viability (Fig. 4) and mitochondrial membrane potential (Fig. S3) were reduced or abolished by fulvestrant, G15, L-NAME, UO126, wortmannin and SB203580. The involvement of eNOS, iNOS, Akt, ERK1/2 and p38 MAPK was confirmed by western blot analysis of their expression or activation. Thus, in the physiological conditions, both genistein and 17 $\beta$-estradiol increased eNOS, Akt, ERK1/2 and p38 MAPK activation (Figs. 5A, S4A and S4C, S5A and S5C, S6A and S6C, S7A and S7C), while causing either no effects or a slight decrease of iNOS expression at $100 \mathrm{nM}$ (Figs. 5B, S8A and S8C).

In $\mathrm{H} 9 \mathrm{C} 2$ stimulated with hydrogen peroxide, eNOS, Akt, ERK1/2 and p38 MAPK activation was reduced (Figs. 5A, S4B and S4D, S5B and S5D, S6B and S6D, S7B and S7D) whereas iNOS expression was increased in comparison with control (Figs. 5B, S8B and S8D). Notably, the pretreatment with genistein and $17 \beta$-estradiol counteracted the inhibition of eNOS (Figs. 5A, S4B and S4D) and the increased expression of iNOS (Figs. 5B, S8B and S8D). All inhibitors were able to prevent the effects of genistein and $17 \beta$-estradiol both in physiological and peroxidative conditions (Figs. S4-S8).

The protective effects elicited by genistein and $17 \beta$-estradiol against oxidative stress were confirmed by the finding of a 

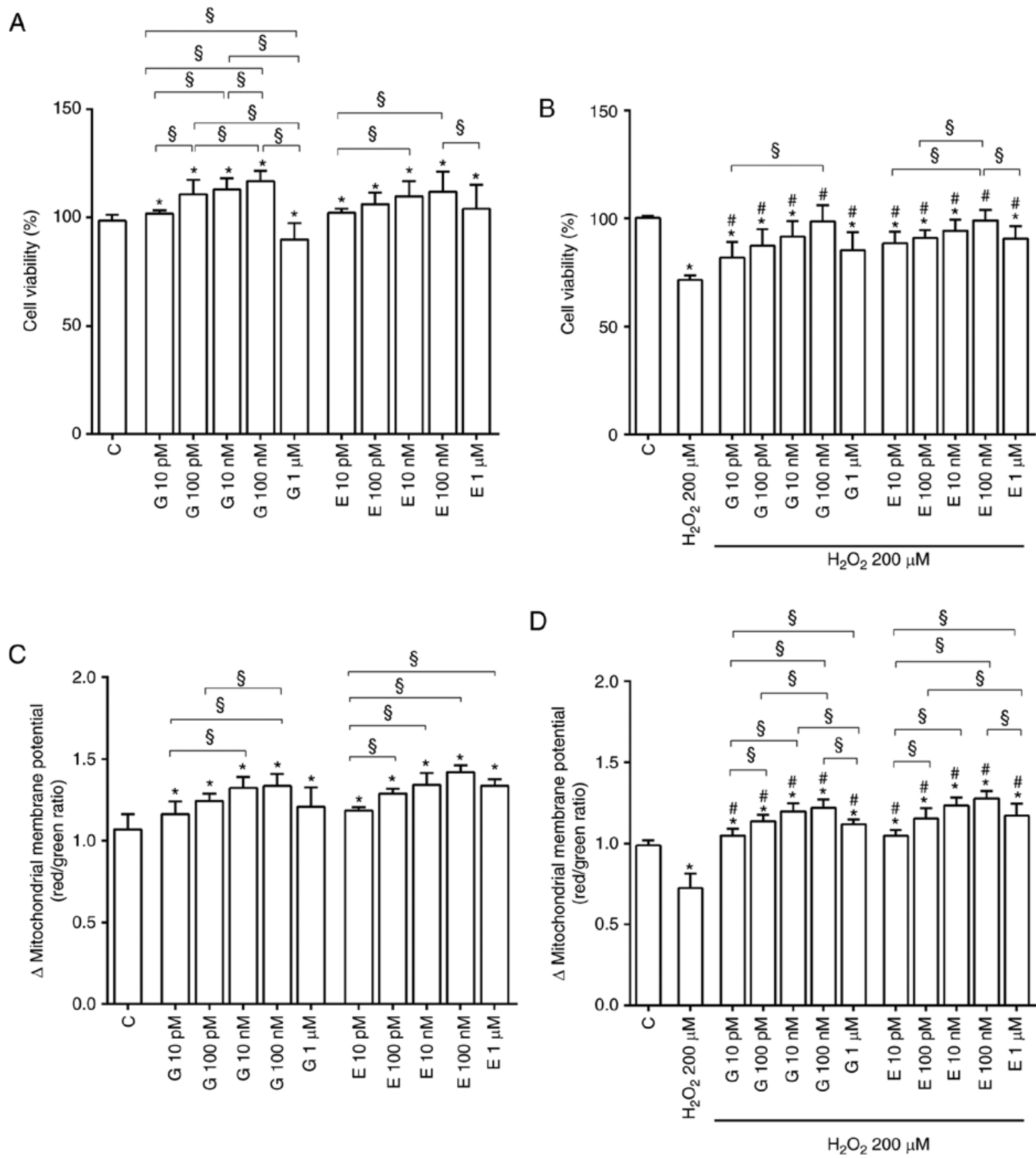

Figure 1. Effects of genistein and $17 \beta$-estradiol on cell viability and mitochondrial membrane potential of $\mathrm{H} 9 \mathrm{C} 2$ cultured in physiological and peroxidative conditions. Effects of genistein (G) $10 \mathrm{pM}, 100 \mathrm{pM}, 10 \mathrm{nM}, 100 \mathrm{nM}, 1 \mu \mathrm{M}$ for $30 \mathrm{~min}$ and $17 \beta$-estradiol (E) $10 \mathrm{pM}, 100 \mathrm{pM}, 10 \mathrm{nM}, 100 \mathrm{nM}, 1 \mu \mathrm{M}$ for $30 \mathrm{~min}$, on cell viability and mitochondrial membrane potential, are show in physiological (A) and (C) and peroxidative (B) and (D) conditions. C=Control. Reported data are means \pm SD of five independent experiments. ${ }^{*} \mathrm{P}<0.05$ vs. C; ${ }^{~} \mathrm{P}<0.05$ vs. $\mathrm{H}_{2} \mathrm{O}_{2} 200 \mu \mathrm{M}$. Square brackets indicate significance between groups $\left({ }^{\circledR} \mathrm{P}<0.05\right)$.

reduction of intracellular ROS release (Fig. 6A) and an increase of GSH production (Fig. 6B).

Effects of genistein and $17 \beta$-estradiol on mitochondrial oxygen consumption. As shown in Fig. 6C, both genistein and $17 \beta$-estradiol increased mitochondrial oxygen consumption in $\mathrm{H} 9 \mathrm{C} 2$-cultured physiological conditions at any doses. Moreover, they were able to counteract the effects of hydrogen peroxide.

Effects of genistein and $17 \beta$-estradiol on NO release. As shown in Fig. 7A, in physiological conditions genistein and
$17 \beta$-estradiol increased NO release with a maximum effect at $100 \mathrm{nM}$. Both agents were able to counteract the effects of hydrogen peroxide on NO release (Fig. 7B).

Fig. 7C and D shows that, the presence of various inhibitors, the effects of genistein and $17 \beta$-estradiol on NO release by $\mathrm{H} 9 \mathrm{C} 2$ cultured in physiological and peroxidative conditions were abolished.

\section{Discussion}

The cardiovascular benefits exerted by estrogens have been widely described. For instance, in postmenopausal 
A

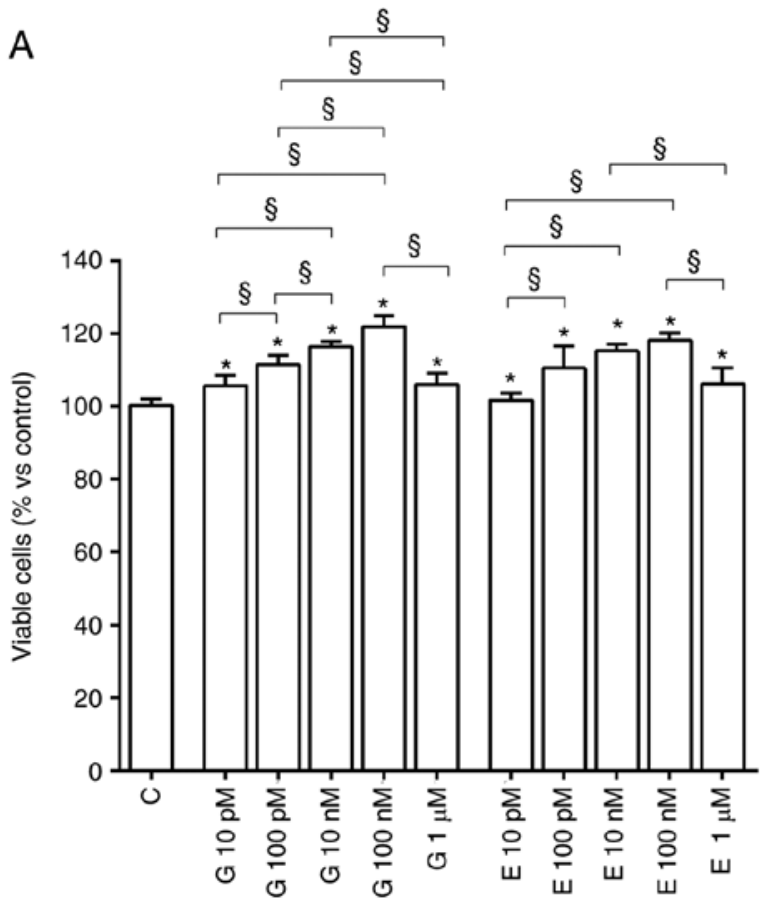

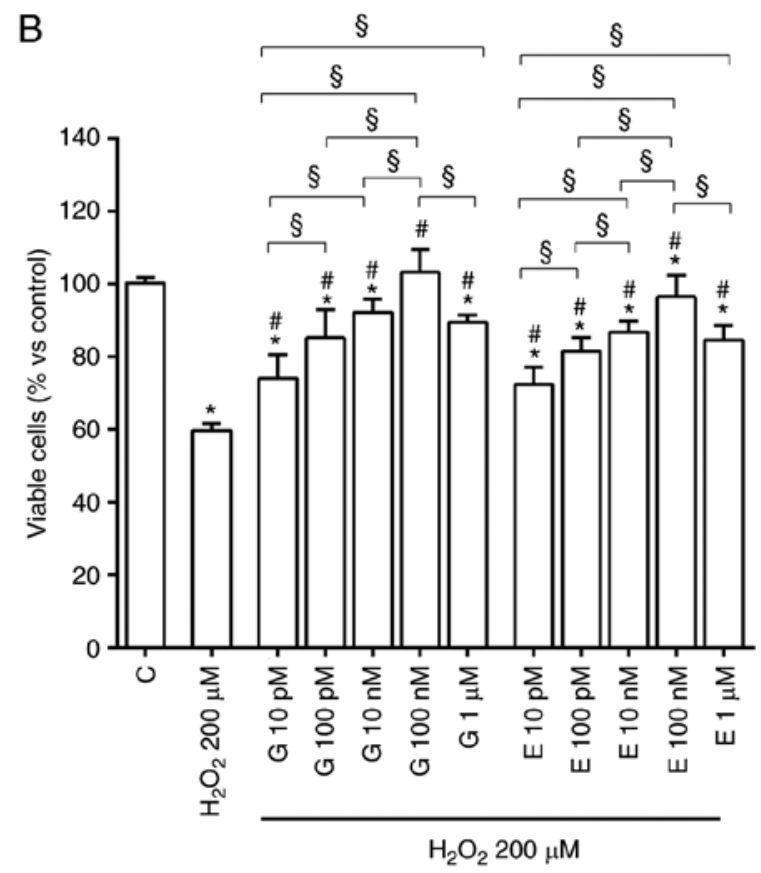

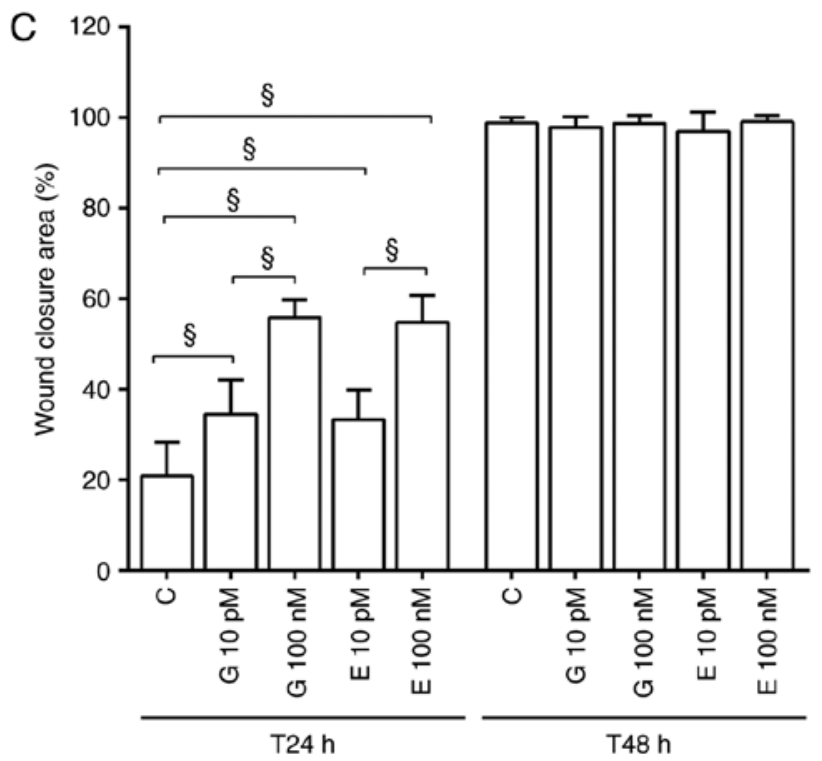

Figure 2. Effects of genistein and $17 \beta$-estradiol on $\mathrm{H} 9 \mathrm{C} 2$ proliferation in physiological (A) and peroxidative (B) conditions and $\mathrm{H} 9 \mathrm{C} 2$ migration (C). Abbreviations are as in Fig. 1. Reported data are means \pm SD of five independent experiments. ${ }^{*} \mathrm{P}<0.05$ vs. C; ${ }^{\#} \mathrm{P}<0.05$ vs. $\mathrm{H}_{2} \mathrm{O}_{2} 200 \mu \mathrm{M}$. Square brackets indicate significance between groups $\left({ }^{\S} \mathrm{P}<0.05\right)$.

women coronary heart disease has been linked to loss of estrogen protection, and estrogen administration has been reported to be associated with reduced cardiovascular risk factors (10). Furthermore, in anesthetized pig, the administration of $17 \beta$-estradiol was shown to induce vasodilation through NO release (10).

Nevertheless, estrogen therapy has been associated with increased incidence of complications. For this reason, alternative agents related to estrogens, among which phytoestrogens, have gained wide attention (22). Thus, epidemiological studies have revealed low rates of cardiovascular diseases (CVD) among Asian populations whose diet is rich in phytoestrogens. This finding would suggest a plausible causal inverse relationship between phytoestrogens and CVD $(13,23-26)$. However, up to-date, information about the cellular mechanisms underlying the cardiovascular effects of phytoestrogens is scarce.

The results obtained with our study have shown, to the best of our knowledge, for the first time that genistein plays an important role in the modulation of cell viability, proliferation/migration, mitochondrial membrane potential and oxygen consumption in $\mathrm{H} 9 \mathrm{C} 2$, cultured either in physiological or pathological conditions. In addition, cell cycle analysis revealed an increase in the percentage of $\mathrm{H} 9 \mathrm{C} 2$ cultured in physiological conditions, in $\mathrm{S}$ phase in response to genistein. Moreover, in peroxidative conditions, a reduction of apoptosis and an 
A

Apoptosis

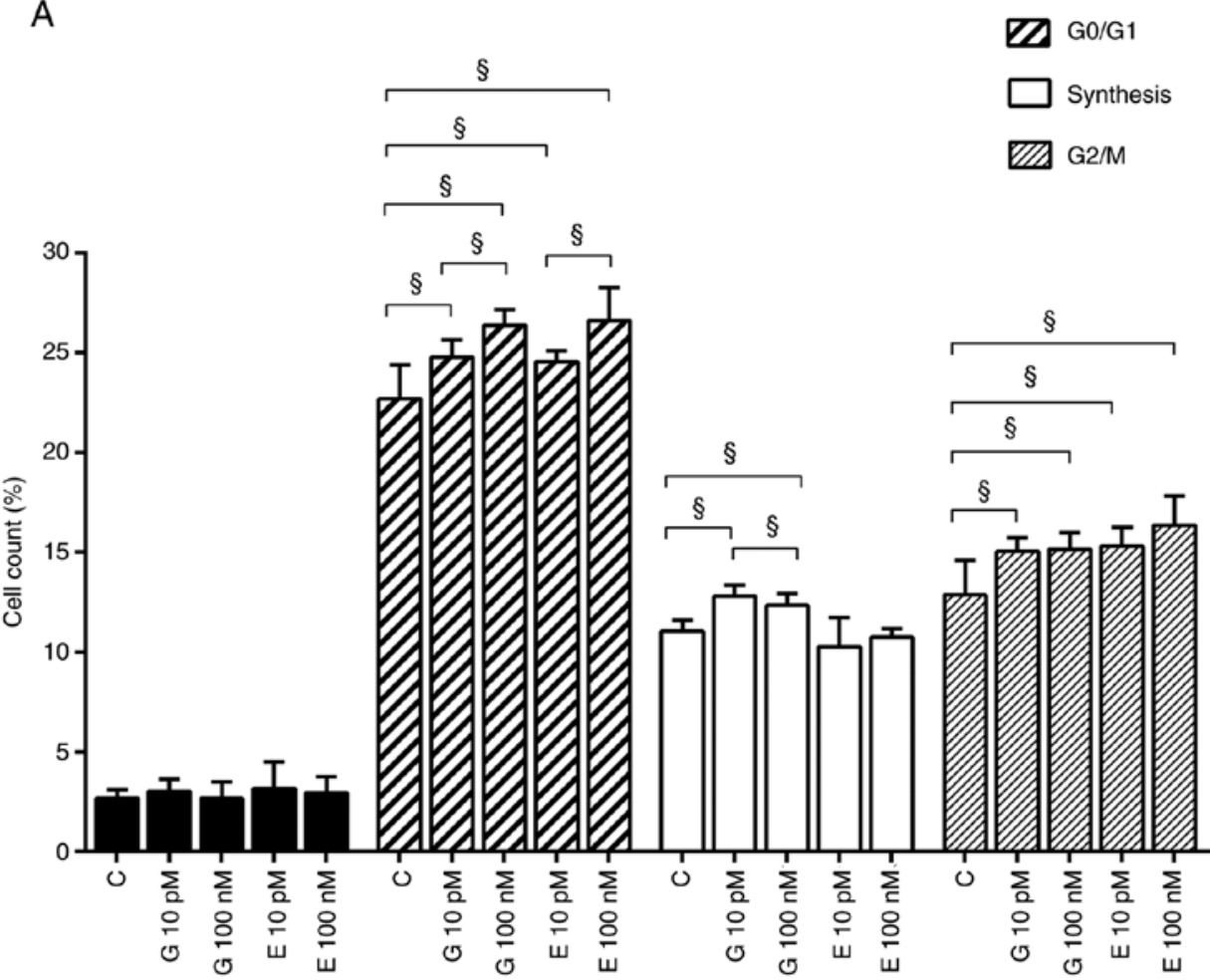

B

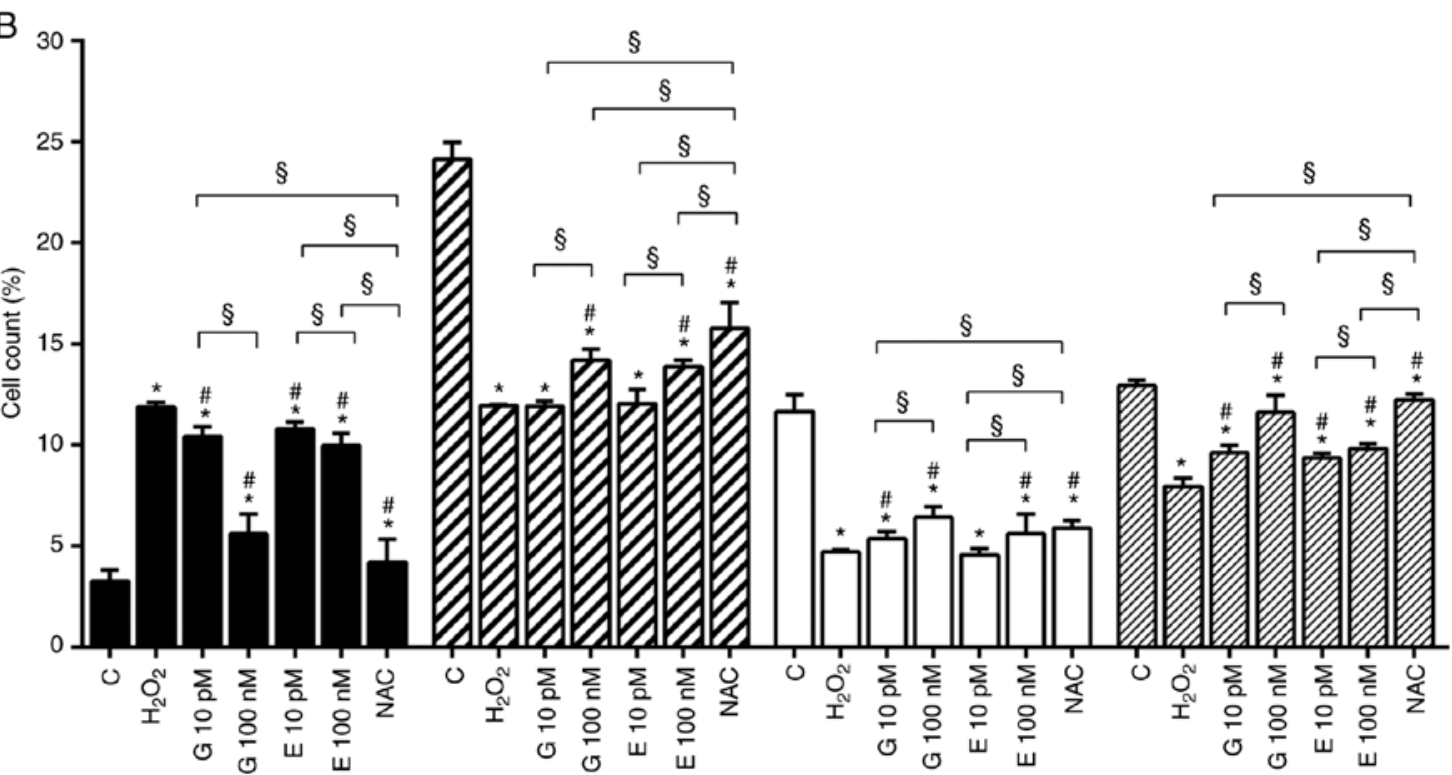

Figure 3. Effects of genistein and 17ß-estradiol on cell cycle in H9C2 cultured in physiological (A) and peroxidative (B) conditions. Cell cycle distribution was measured by flow cytometry using propidium iodide staining and quantitative analysis of apoptosis, G0/G1, synthesis, and G2/M phase is shown in a bar graph form. Abbreviations are as in previous figures. Reported data are means $\pm \mathrm{SD}$ of five independent experiments. ${ }^{*} \mathrm{P}<0.05$ vs. $\mathrm{C} ;{ }^{\#} \mathrm{P}<0.05$ vs. $200 \mu \mathrm{M} \mathrm{H} \mathrm{H}_{2} \mathrm{O}_{2}$. Square brackets indicate significance between groups $\left({ }^{\$} \mathrm{P}<0.05\right)$.

increase of $\mathrm{S}$ and $\mathrm{G} 2 / \mathrm{M}$ phases was observed in $\mathrm{H} 9 \mathrm{C} 2$ treated with genistein. Similar effects were observed in the presence of estradiol. Our findings regarding cell viability would not confirm those obtained by Gutiérrez-Venegas et al (27) who showed an absence of effects of genistein in $\mathrm{H} 9 \mathrm{C} 2$. In those experiments, however, genistein was administered with lipopolysaccharide and for longer periods. By contrast, our data confirm previous results obtained in $\mathrm{H} 9 \mathrm{C} 2$ cultured in an experimental setup, the chemical-induced hypoxic condition (28), which would be more similar to our experimental model.
The doses of genistein were comparable to the ones previously used and were in the range of nutritional concentrations $(29,30)$. Moreover, the effects of genistein were similar to those elicited by $17 \beta$-estradiol, which was administered in a concentration range that can commonly be found in menstrual or menopausal women $(31,32)$. In addition, similar doses of estradiol affected calcium movements and modulated hypertrophic signalling in the same cellular model $(33,34)$.

In our study, the use of specific inhibitors, allowed us to highlight the involvement of pathways related to Akt, ERK1/2, 

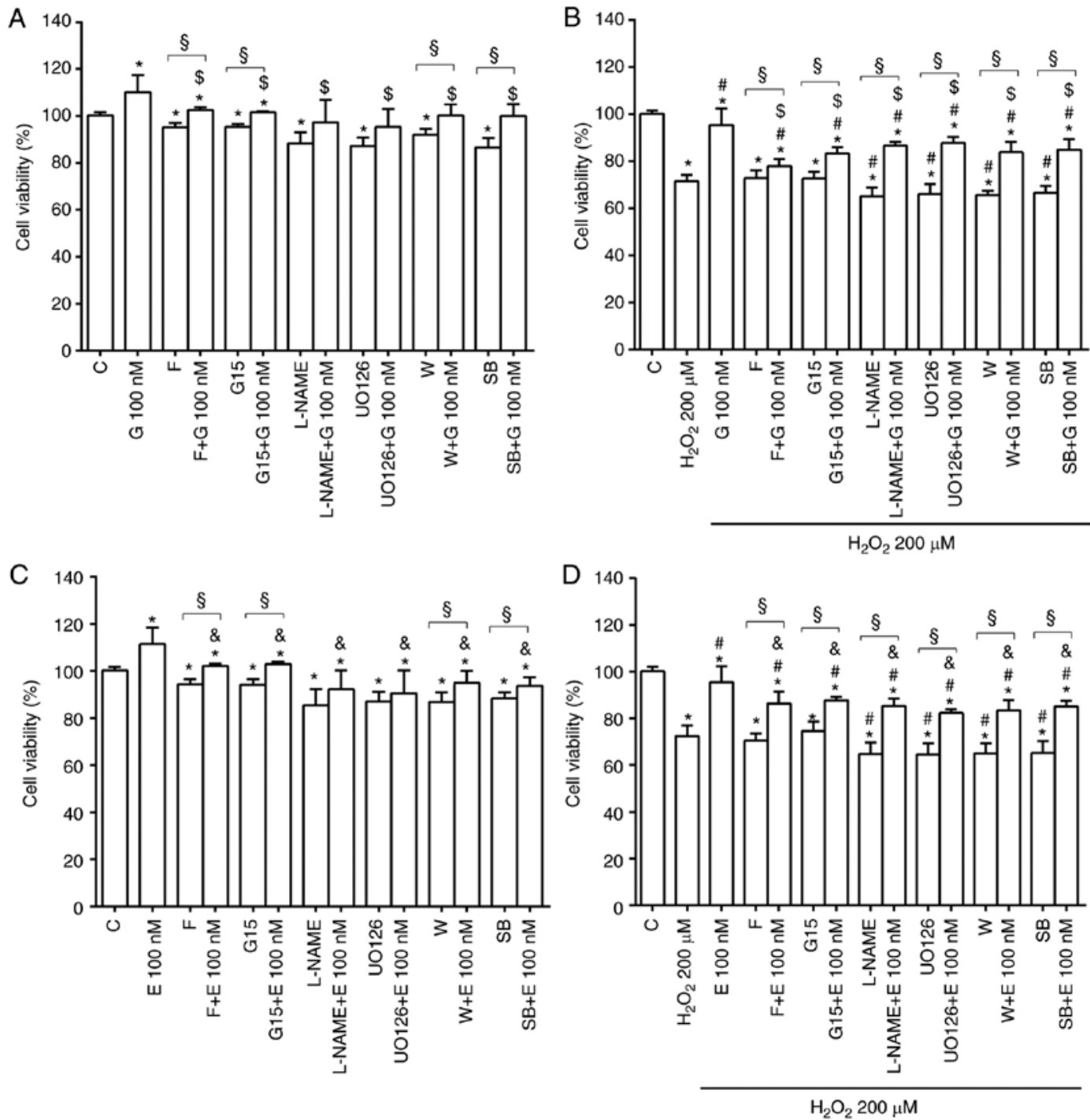

Figure 4. Effects of genistein (A and B) and 17ß-estradiol (C and D) on cell viability of H9C2 cultured in physiological (A and C) and peroxidative (B and D) conditions, in the presence/absence of various inhibitors. Abbreviations are as previous figures. F (fulvestrant $100 \mathrm{nM}$ ); G15 (100 nM); L-NAME $(100 \mathrm{nM}) ; \mathrm{UO} 126(100 \mathrm{nM}) ; \mathrm{W}$ (wortmannin $100 \mathrm{nM})$; SB (SB203580 $100 \mathrm{nM})$. Reported data are means \pm SD of five independent experiments. "P<0.05 vs. C; ${ }^{\#} \mathrm{P}<0.05$ vs. $\mathrm{H}_{2} \mathrm{O}_{2} 200 \mu \mathrm{M} ;{ }^{\$} \mathrm{P}<0.05$ vs. $\mathrm{G} ;{ }^{\&} \mathrm{P}<0.05$ vs. E. Square brackets indicate significance between groups ( $\left.{ }^{\circledR} \mathrm{P}<0.05\right)$.
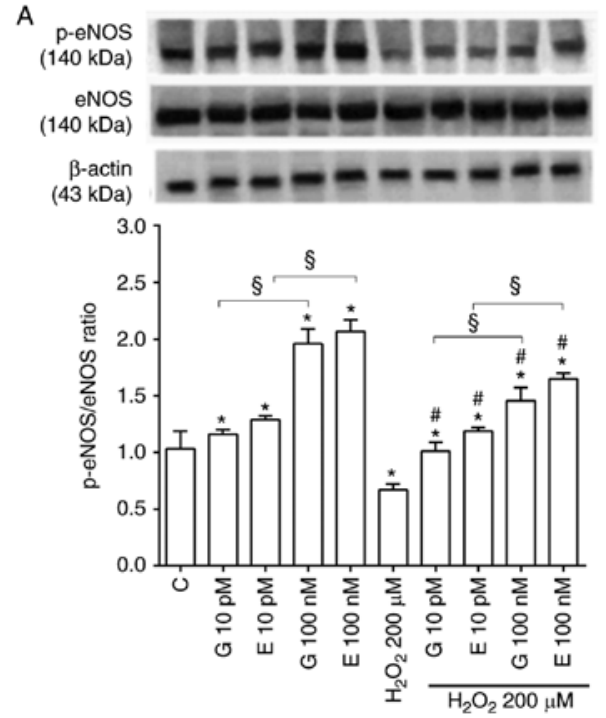
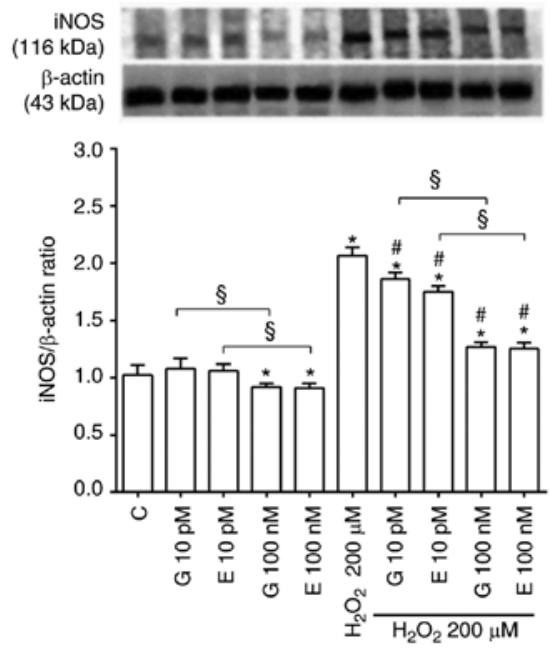

Figure 5. Effects of genistein and 17 $\beta$-estradiol on phosphorylated and total eNOS/ $\beta$-actin (A) and iNOS expression (B) in H9C2 cultured in physiological and peroxidative conditions. Abbreviations are as in previous figures. Reported data are means $\pm \mathrm{SD}$ of five independent experiments. ${ }^{*} \mathrm{P}<0.05$ vs. $\mathrm{C}$; ${ }^{*} \mathrm{P}<0.05$ vs. $\mathrm{H}_{2} \mathrm{O}_{2} 200 \mu \mathrm{M}$. Square brackets indicate significance between groups $\left({ }^{\S} \mathrm{P}<0.05\right)$. 

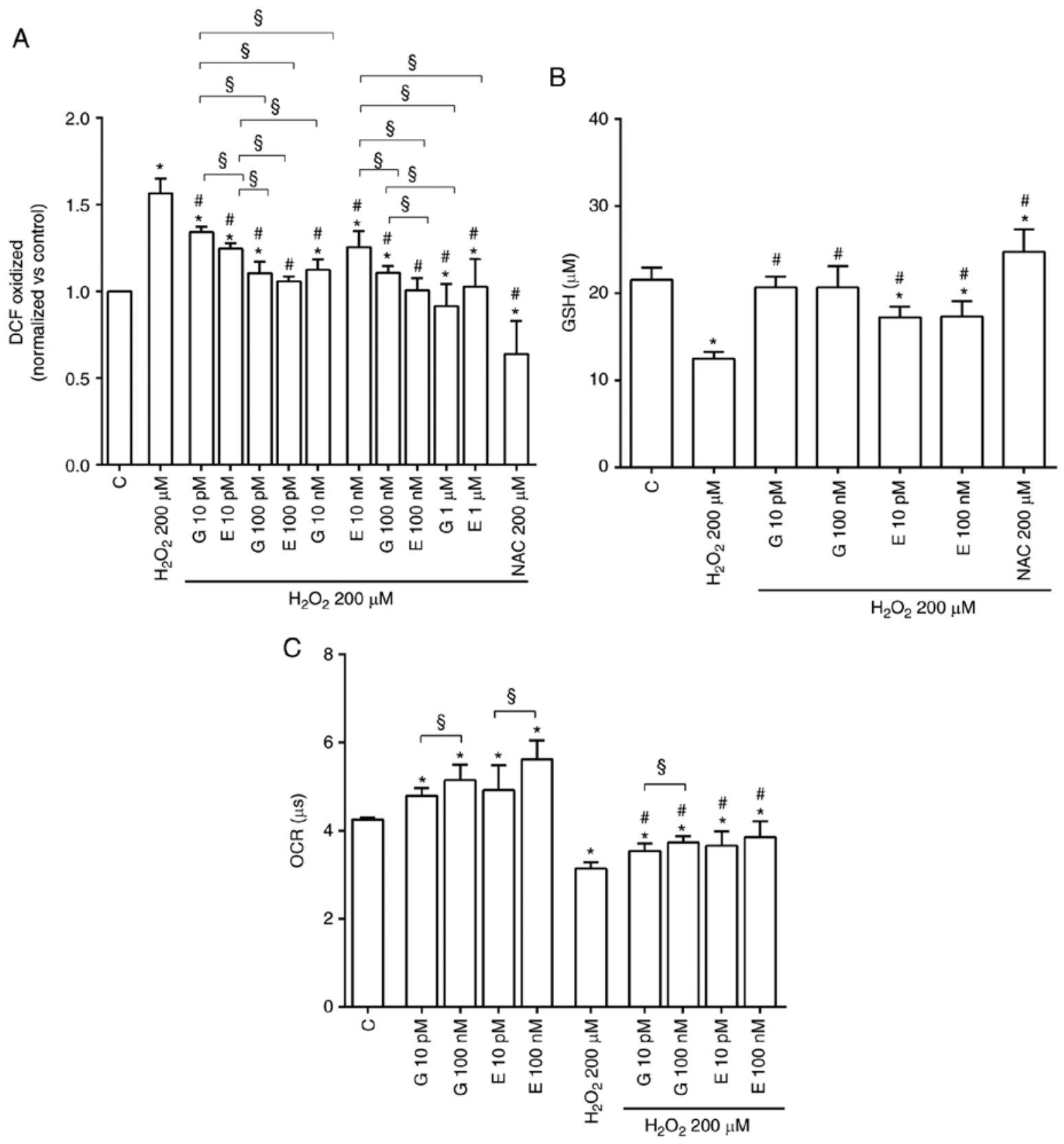

Figure 6. Effects of genistein and 17ß-estradiol on reactive oxygen species (ROS) (A) and glutathione (GSH) (B) production in peroxidative conditions and oxygen consumption rate ( $\mathrm{OCR})(\mathrm{C})$ in physiological/peroxidative conditions by $\mathrm{H} 9 \mathrm{C} 2$. Abbreviations are as in previous figures. NAC (N acetyl-cysteine $200 \mu \mathrm{M}$ ). Reported data are means $\pm \mathrm{SD}$ of five independent experiments. ${ }^{*} \mathrm{P}<0.05$ vs. $\mathrm{C}$; ${ }^{\#} \mathrm{P}<0.05$ vs. $\mathrm{H}_{2} \mathrm{O}_{2} 200 \mu \mathrm{M}$. Square brackets indicate significance between groups $\left({ }^{\$} \mathrm{P}<0.05\right)$.

and $\mathrm{p} 38 \mathrm{MAPK}$ in the mechanisms of action of both genistein and $17 \beta$-estradiol on cell viability and mitochondrial membrane potential. Their involvement was also confirmed by western blot analysis. Those findings are in agreement with previous ones showing the role of the above kinases in the protective effects elicited by genistein and $17 \beta$-estradiol in $\mathrm{H} 9 \mathrm{C} 2(30,35)$.

The observation of an improvement of mitochondrial membrane potential and oxygen consumption in response to genistein and $17 \beta$-estradiol is of particular relevance and could be involved in the mechanism of protection exerted by estrogens and phytoestrogens against peroxidation. Thus, mitochondrial membrane potential has been considered a good indicator of the energy status of the mitochondria and, above all, of cellular homeostasis. Interestingly, changes in mitochondrial membrane potential are reportedly correlated with cell survival or death through apoptosis (36-38).

Furthermore, the improvement of mitochondrial function could be at the basis of increased cell proliferation/migration observed in response to both genistein and estradiol up to $100 \mathrm{nM}$. Concerning this issue, data related to the phytoestrogens are quite new. Hence, previous findings collected in vascular smooth muscle cells or cardiac fibroblasts showed inhibitory effects elicited by genistein (39-41). Regarding estradiol, our results are in agreement with previous ones showing either an increase or decrease of cardiomyoblast proliferation at low and high estrogenic concentrations, respectively (42).

In $\mathrm{H} 9 \mathrm{C} 2$ cultured in physiological conditions, estrogens and phytoestrogens were shown, for the first time, to acutely 
A
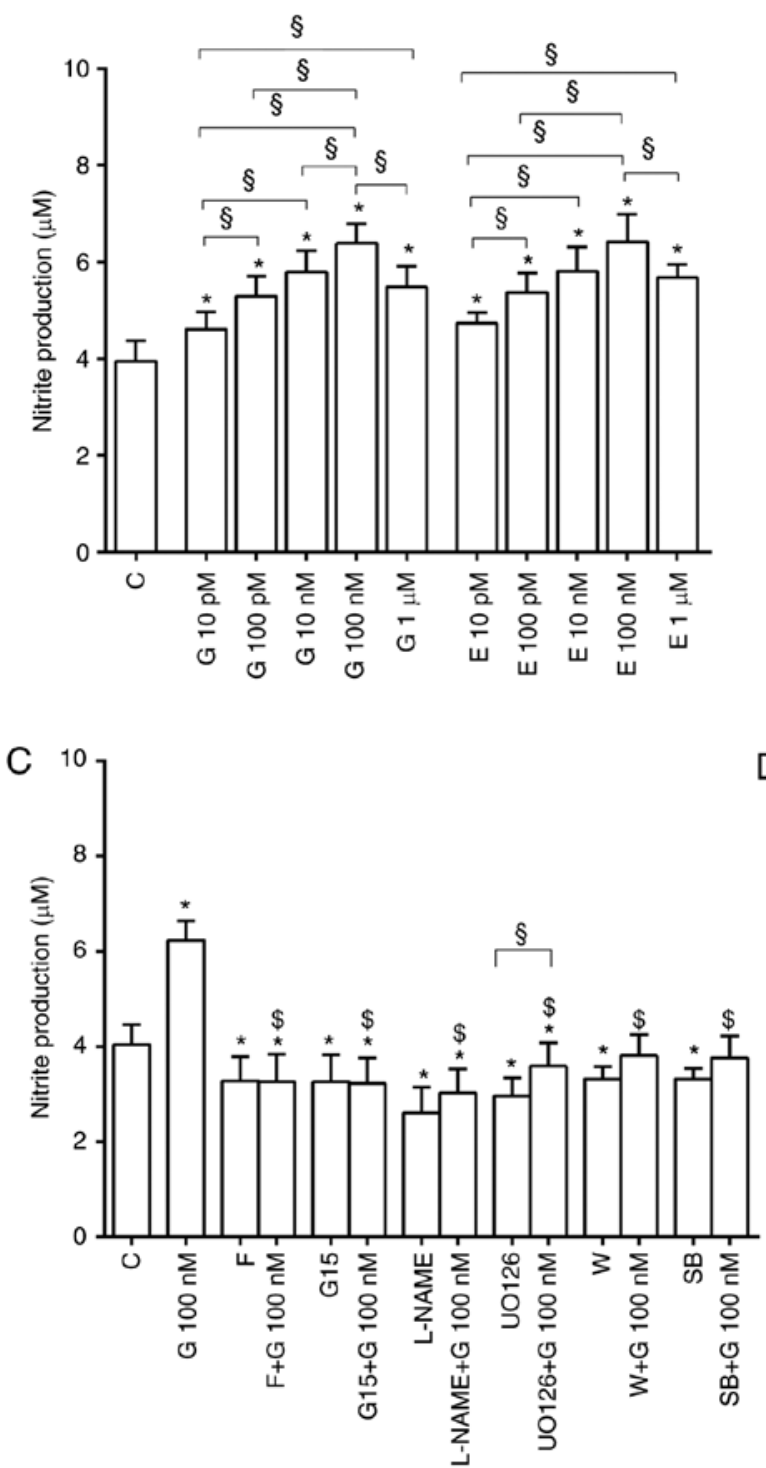

B
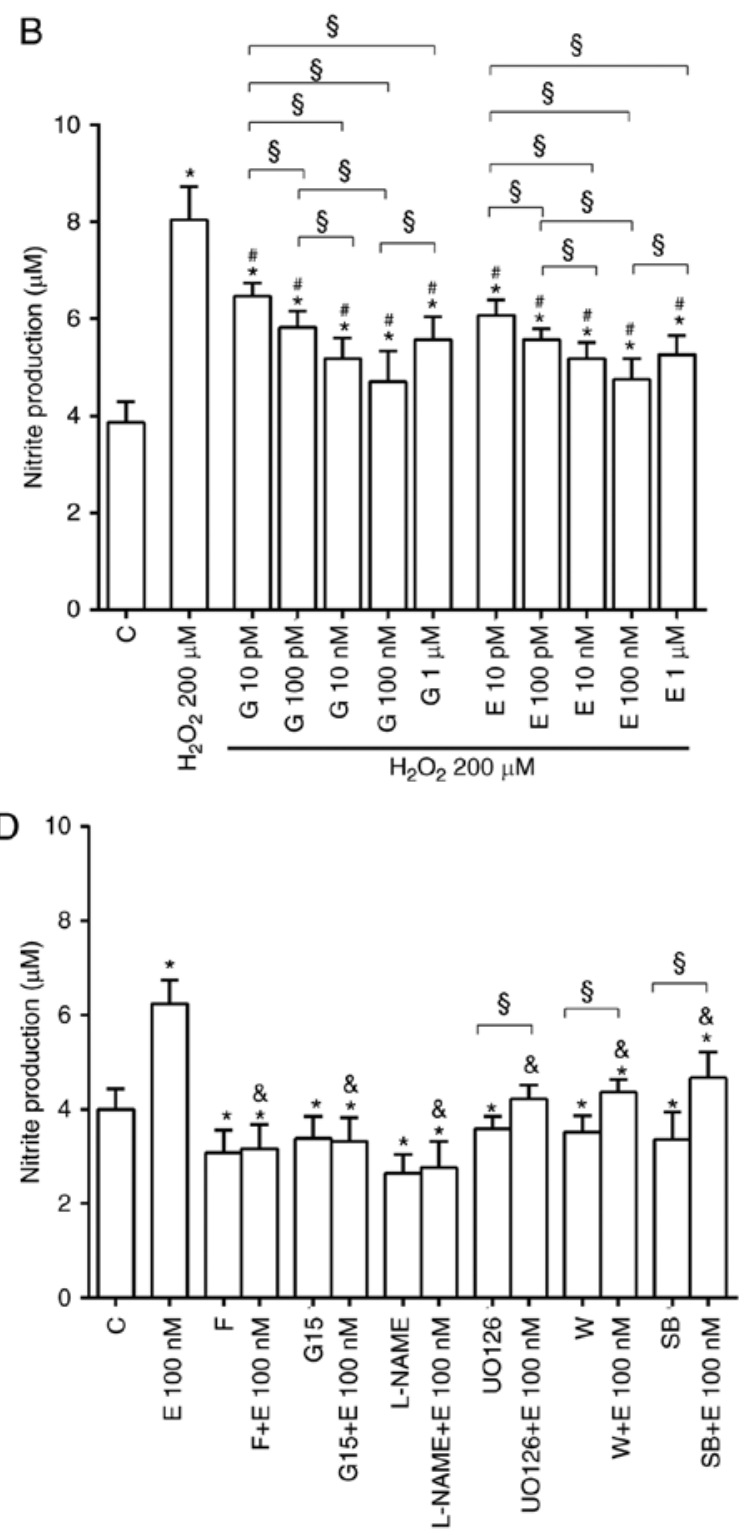

Figure 7. Effects of genistein and $17 \beta$-estradiol on NO release by H9C2 cultured in physiological (A) and peroxidative (B) conditions and in the presence/absence of various inhibitors (C and D). Abbreviations are as in previous figures. Reported data are means \pm SD of five independent experiments. ${ }^{*} \mathrm{P}<0.05$ vs. $\mathrm{C} ;{ }^{\#} \mathrm{P}<0.05$ vs. $\mathrm{H}_{2} \mathrm{O}_{2} 200 \mu \mathrm{M} ;{ }^{~} \mathrm{P}<0.05$ vs G; ${ }^{\circledR} \mathrm{P}<0.05$ vs. E. Square brackets indicate significance between groups $\left({ }^{\S} \mathrm{P}<0.05\right)$.

increase NO release. As observed for cell viability and mitochondrial membrane potential, those effects were related to the involvement of ERK1/2, p38MAPK and Ak-related pathways, which are well known to play a key role in eNOS activation (43-45). By contrast, in peroxidative conditions, the two agents reduced the excessive release of NO caused by hydrogen peroxide. These results are particularly relevant if we consider the different role played by NO. NO is synthesized from L-arginine by three isoforms of NOS (46). These are the inducible and calcium-independent NOS (iNOS), the constitutive and calcium-dependent, neuronal NOS (nNOS) and the constitutive and calcium-dependent, endothelial NOS (eNOS) (47). It is notable that, while NO produced in low concentration, as in the case of the eNOS activation, would act as a messenger and cytoprotective factor via direct interactions with transition metals and other free radicals (48), the stimulation of iNOS and NO overproduction could increase reactive nitrous species (RNS) formation and cause cellular death.
In the present study, eNOS phosphorylation was found to be increased by genistein and $17 \beta$-estradiol in H9C 2 cultured in physiological conditions. By contrast, when H9C2 cardiomyoblasts were subjected to peroxidation, eNOS activation was slightly decreased in comparison with the strong iNOS expression; this could explain the findings regarding NO production. Since these effects were counteracted by estrogens and phytoestrogens, the modulation of the imbalance of the various isoforms of NOS and NO release could be hypothesized to be at basis of the protective effects elicited by genistein and $17 \beta$-estradiol against peroxidation and increased cell death. Our findings are similar to those recently reported by Ma et al who showed a role for NO in the antiapoptotic effects of bioactive organosulfur compounds of garlic, such as allicin, in H9C2 (49). In addition, the biological actions of the polyphenol agent, licochalcone $\mathrm{C}$, against oxidative stress injuries in $\mathrm{H} 9 \mathrm{C} 2$ have been found to be related to the maintenance of the balance between the constitutive and inducible 
isoforms of NOS (50). Finally, recent data by Zuo et al, have shown that Panax ginseng was able to protect cardiomyocytes against ischemic/reperfusion damage by triggering the cascade of the so-called reperfusion injury salvage kinase (RISK) pathways, which involves ERK1/2 and Akt, and the subsequent eNOS-related NO release modulation (51). Interestingly, the pretreatment of $\mathrm{H} 9 \mathrm{C} 2$ with L-NAME, the non-selective NOS inhibitor, was able, not only to reduce the effects of the two agents on NO release, but also on cell viability and mitochondrial membrane potential.

It could therefore be hypothesized that a key role is played by $\mathrm{NO}$ as modulator of mitochondrial function in mediating the protective effects elicited by phytoestrogens and estrogens in $\mathrm{H} 9 \mathrm{C} 2$. Our speculations are supported by previous findings showing an increased oxidative phosphorylation efficiency by $\mathrm{NO}$ and beneficial effects on mitochondrial matrix $\mathrm{pH}$ and mitochondrial membrane potential (52).

The protective effect of genistein and $17 \beta$-estradiol on the cardiomyoblast response to oxidative stress, has been confirmed by the analysis of intracellular ROS release and GSH production (53-56). Oxidative stress, which is caused by the accumulation of intracellular ROS or RNS, is one of the leading factors triggering cardiomyocyte apoptosis by affecting mitochondrial function. Moreover, ROS may have direct detrimental effects on cellular structure and function by modulating myocardial remodeling, which represents a risk factor for CVD. For this reason, inhibiting ROS production or the enhancement of ROS scavenging could be used as a therapeutic strategy for treating CVD. Those species are generated constantly in vivo, and can cause oxidative damage to DNA, proteins and lipids resulting in cellular apoptotic death. Activation of the PI3K/Akt pathway in H9C2 cells can suppress apoptosis and promote cell survival (56). Therefore, the results we have obtained would suggest that both genistein and $17 \beta$-estradiol can protect $\mathrm{H} 9 \mathrm{C} 2$ from peroxidation through the modulation of mitochondrial function by the involvement of Akt pathway. Our data are in agreement with those obtained by Zuo et al regarding the role of ginseng in H9C2 (51) and are similar to what was found in other cell types $(30,25,57-61)$.

The involvement of ERs and GPER receptors in the mechanisms of action of genistein and $17 \beta$-estradiol in H9C2 has been confirmed by using fulvestrant and G15. Our findings are in line with previous observations on the role of both estrogenic receptors in the cardiovascular effects of estrogens and phytoestrogens. In particular, although ERs are involved in the cardio-protection exerted by $17 \beta$-estradiol, its protective effects have been also described in the absence of ERs (62). Those findings lead to speculations about the existence of alternative receptors such as GPER and signalling pathways involved in $17 \beta$-estradiol-mediated regulation of cardiovascular function. In particular, GPER activation leads to the downstream enhancement of signalling molecules, such as ERK1/2 and Akt (63). Concerning genistein, our data regarding the role of GPER in the cardiac protective effects are quite new, since previous findings mainly involved the reproductive system.

In conclusion, this study has shown, to the best of our knowledge, for the first time that, genistein improves viability/proliferation and mitochondrial function of $\mathrm{H} 9 \mathrm{C} 2$ through mechanisms not so different from those suggested by the effects of estradiol. In particular, ERs and GPER receptors, the RISK pathway and the modulation of NO release by eNOS/iNOS could play a role in exerting their physiological effects and protection against peroxidation. These findings could be of clinical relevance for the management of cardiovascular disease in postmenopausal women, in which the use of phytoestrogens may be an alternative hormonal therapy for the amelioration of postmenopausal CVD.

\section{Aknowledgements}

We would like to thank Azienda Ospedaliera Universitaria della Carità, Novara, for their assistance in purchasing materials.

\section{Funding}

This study was (partially) funded by the AGING ProjectDepartment of Excellence: DIMET, Università del Piemonte Orientale.

\section{Availability of data and materials}

All data generated or analyzed during this study are included in this published article.

\section{Authors' contributions}

EG and SG contributed to the conception and design of the study as well as the drafting and revising of the manuscript. SF, GR, GC and CL contributed to performing of the experiments, the analysis and interpretation of data, and the drafting and revising of the manuscript. DM was involved in the design, writing and revising of the manuscript. All authors have approved the final version of the manuscript.

\section{Ethics approval and consent to participate}

Not applicable.

\section{Patient consent for publication}

Not applicable.

\section{Competing interests}

The authors have no competing insterests to disclose.

\section{References}

1. Radak Z, Zhao Z, Goto S and Koltai E: Age-associated neuro-degeneration and oxidative damage to lipids, proteins and DNA. Mol Aspects Med 32: 305-315, 2011.

2. Murphy E and Steenbergen C: Mechanisms underlying acute protection from cardiac ischemia-reperfusion injury. Physiol Rev 88: 581-609, 2008.

3. Guan LY, Fu PY, Li PD, Li ZN, Liu HY, Xin MG and Li W: Mechanisms of hepatic ischemia-reperfusion injury and protective effects of nitric oxide. World J Gastrointest Surg 6: 122-128, 2014.

4. Hu L, Zhou L, Wu X, Liu C, Fan Y and Li Q: Hypoxic preconditioning protects cardiomyocytes against hypoxia/reoxygenation injury through AMPK/eNOS/PGC-1 $\alpha$ signaling pathway. Int J Clin Exp Pathol 7: 7378-7388, 2014. 
5. Gealekman O, Abassi Z, Rubinstein I, Winaver J and Binah O Role of myocardial inducible nitric oxide synthase in contractile dysfunction and beta-adrenergic hyporesponsiveness in rats with experimental volume-overload heart failure. Circulation 105 : 236-243, 2002

6. Yang B, Larson DF and Watson RR: Modulation of iNOS activity in age-related cardiac dysfunction. Life Sci 75: 655-667, 2004.

7. Ganai AA and Faroogi H: Bioactivity of genistein: A review of in vitro and in vivo studies. Biomed Pharmacother 76: 30-38, 2015

8. Si H and Liu D: Phytochemical genistein in the regulation of vascular function: New insights. Curr Med Chem 14: 2581-2589, 2007.

9. Si H, Yu J, Jiang H, Lum H and Liu D: Phytoestrogen genistein up-regulates endothelial nitric oxide synthase expression via activation of cAMP response element-binding protein in human aortic endothelial cells. Endocrinology 153: 3190-3198, 2012.

10. Grossini E, Molinari C, Mary DA, Uberti F, Caimmi PP, Surico N and Vacca G: Intracoronary genistein acutely increases coronary blood flow in anesthetized pigs through beta-adrenergic mediated nitric oxide release and estrogenic receptors. Endocrinology 149 : 2678-2687, 2008.

11. Schmitt CA and Dirsch VM: Modulation of endothelial nitric oxide by plant-derived products. Nitric Oxide 21: 77-91, 2009.

12. Meng Y, Zhang Y, Ma Z, Zhou H, Ni J, Liao H and Tang Q: Genistein attenuates pathological cardiac hypertrophy in vivo and in vitro. Herz 44: 247-256, 2019.

13. Surico D, Ercoli A, Farruggio S, Raina G, Filippini D, Mary D, Minisini R, Surico N, Pirisi M and Grossini E: Modulation of oxidative stress by $17 \beta$-estradiol and genistein in human hepatic cell lines in vitro. Cell Physiol Biochem 42: 1051-1062, 2017.

14. Liu F, Cao JG, Li C, Tan JS and Fu XH: Protective effects of 7-difluoromethyl-5,4'-imethoxygenistein against human aorta endothelial injury caused by lysophosphatidyl choline. Mol Cell Biochem 363: 147-155, 2012

15. Yang Y, Nie W, Yuan J, Zhang B, Wang Z, Wu Z and Guo Y: Genistein activates endothelial nitric oxide synthase in broiler pulmonary arterial endothelial cells by an Akt-dependent mechanism. Exp Mol Med 42: 768-776, 2010.

16. De Cillà S, Farruggio S, Vujosevic S, Raina G, Filippini D, Gatti V, Clemente N, Mary D, Vezzola D, Casini G, et al: Anti-vascular endothelial growth factors protect retinal pigment epithelium cells against oxidation by modulating nitric oxide release and autophagy. Cell Physiol Biochem 42: 1725-1738, 2017.

17. Grossini E, Farruggio S, Qoqaiche F, Raina G, Camillo L, Sigaudo L, Mary D, Surico N and Surico D: Monomeric adiponectin modulates nitric oxide release and calcium movements in porcine aortic endothelial cells in normal/high glucose conditions. Life Sci 161: 1-9, 2016.

18. Surico D, Farruggio S, Marotta P, Raina G, Mary D, Surico N, Vacca $G$ and Grossini E: Human chorionic gonadotropin protects vascular endothelial cells from oxidative stress by apoptosis inhibition, cell survival signalling activation and mitochondrial function protection. Cell Physiol Biochem 36: 2108-2120, 2015

19. Grossini E, Bellofatto K, Farruggio S, Sigaudo L, Marotta P, Raina G, De Giuli V, Mary D, Pollesello P, Minisini R, et al Levosimendan inhibits peroxidation in hepatocytes by modulating apoptosis/autophagy interplay. PLoS One 10: e0124742, 2015.

20. Grossini E, Gramaglia C, Farruggio S, Bellofatto K, Anchisi C, Mary D, Vacca G and Zeppegno P: Asenapine increases nitric oxide release and protects porcine coronary artery endothelial cells against peroxidation. Vascul Pharmacol 60: 127-141, 2014.

21. Riccardi C and Nicoletti I: Analysis of apoptosis by propidium iodide staining and flow cytometry. Nat Protoc 1: 1458-1461, 2006.

22. Gencel VB, Benjamin MM, Bahou SN and Khalil RA: Vascular effects of phytoestrogens and alternative menopausal hormone therapy in cardiovascular disease. Mini Rev Med Chem 12: 149-174, 2012

23. Lissin LW and Cooke JP: Phytoestrogens and cardiovascular health. J Am Coll Cardiol 35: 1403-1410, 2000.

24. Behl C, Skutella T, Lezoualc'h F, Post A, Widmann M, Newton CJ and Holsboer F: Neuroprotection against oxidative stress by estrogens: Structure-activity relationship. Mol Pharmacol 51: 535-541, 1997.

25. Xi YD, Yu HL, Ma WW, Ding BJ, Ding J, Yuan LH, Feng JF and Xiao R: Genistein inhibits mitochondrial-targeted oxidative damage induced by beta-amyloid peptide, $25-35$ in PC12 cells. J Bioenerg Biomembr 43: 399-407, 2011.

26. Nuedling S, Kahlert S, Loebbert K, Doevendans PA, Meyer R, Vetter $\mathrm{H}$ and Grohé C: 17 Beta-estradiol stimulates expression of endothelial and inducible NO synthase in rat myocardium in-vitro and in-vivo. Cardiovasc Res 43: 666-674, 1999.
27. Gutiérrez-Venegas G, Torras-Ceballos A, Gómez-Mora JA and Fernández-Rojas B: Luteolin, quercetin, genistein and quercetagetin inhibit the effects of lipopolysaccharide obtained from Porphyromonas gingivalis in H9c2 cardiomyoblasts. Cell Mol Biol Lett 22: 19, 2017.

28. Shi YN, Zhang XQ, Hu ZY, Zhang CJ, Liao DF, Huang HL and Qin L: Genistein protects H9c2 cardiomyocytes against chemical hypoxia-induced injury via inhibition of apoptosis. Pharmacology 103: 282-290, 2019.

29. Sienkiewicz P, Surazyński A, Pałka J and Miltyk W: Nutritional concentration of genistein protects human dermal fibroblasts from oxidative stress-induced collagen biosynthesis inhibition through IGF-I receptor-mediated signaling. Acta Pol Pharm 65: 203-211, 2008

30. Hu WS, Lin YM, Ho TJ, Chen RJ, Li YH, Tsai FJ, Tsai CH, Day $\mathrm{CH}$, Chen TS and Huang CY: Genistein suppresses the isoproterenol-treated $\mathrm{H} 9 \mathrm{c} 2$ cardiomyoblast cell apoptosis associated with P-38, Erk1/2, JNK, and $\mathrm{NF \kappa B}$ signaling protein activation. Am J Chin Med 41: 1125-1136, 2013.

31. Itagaki T, Shimizu I, Cheng X, Yuan Y, Oshio A, Tamaki K, Fukuno H, Honda H, Okamura Y and Ito S: Opposing effects of oestradiol and progesterone on intracellular pathways and activation processes in the oxidative stress induced activation of cultured rat hepatic stellate cells. Gut 54: 1782-1789, 2005.

32. White MM, Zamudio S, Stevens T, Tyler R, Lindenfeld J, Leslie K and Moore LG: Estrogen, progesterone, and vascular reactivity: Potential cellular mechanisms. Endocr Rev 16: 739-751, 1995

33. Yang X, MaoX,Xu G,Xing S,Chattopadhyay A,JinS and SalamaG: Estradiol up-regulates L-type $\mathrm{Ca}^{2+}$ channels via membrane-bound estrogen receptor/phosphoinositide-3-kinase/Akt/cAMP response element-binding protein signaling pathway. Heart Rhythm 15: 741-749, 2018

34. Pai P, Velmurugan BK, Kuo $\mathrm{CH}$, Yen $\mathrm{CY}$, Ho TJ, Lin YM, Chen YF, Lai CH, Day CH and Huang CY: 17 $\beta$-Estradiol and/or estrogen receptor alpha blocks isoproterenol-induced calcium accumulation and hypertrophy via GSK33/PP2A/NFAT3/ANP pathway. Mol Cell Biochem 434: 181-195, 2017.

35. Urata Y, Ihara Y, Murata H, Goto S, Koji T, Yodoi J, Inoue S and Kondo T: 17Beta-estradiol protects against oxidative stress-induced cell death through the glutathione/glutaredoxindependent redox regulation of Akt in myocardiac H9c2 cells. J Biol Chem 281: 13092-13102, 2006.

36. Javadov S and Karmazyn M: Mitochondrial permeability transition pore opening as an endpoint to initiate cell death and as a putative target for cardioprotection. Cell Physiol Biochem 20: $1-22,2007$

37. Ormel $\mathbf{J}$ and De Jonge P: Unipolar depression and the progression of coronary artery disease: Toward an integrative model. Psychother Psychosom 80: 264-274, 2011.

38. Russell JW, Golovoy D, Vincent AM, Mahendru P, Olzmann JA, Mentzer A and Feldman EL: High glucose-induced oxidative stress and mitochondrial dysfunction in neurons. FASEB J 16: 1738-1748, 2002

39. Yu JY, Lee JJ, Lim Y, Kim TJ, Jin YR, Sheen YY and Yun YP: Genistein inhibits rat aortic smooth muscle cell proliferation through the induction of p27kip1. J Pharmacol Sci 107: 90-98, 2008.

40. Tsai YC, Leu SY, Peng YJ, Lee YM, Hsu CH, Chou SC, Yen MH and Cheng PY: Genistein suppresses leptin-induced proliferation and migration of vascular smooth muscle cells and neointima formation. J Mol Med 21: 422-431, 2017.

41. Pillai MS and Shivakumar K: Genistein abolishes nucleoside uptake by cardiac fibroblasts. Mol Cell Biochem 332: 121-125, 2009.

42. Kilić A, Javadov S and Karmazyn M: Estrogen exerts concentration-dependent pro-and anti-hypertrophic effects on adult cultured ventricular myocytes. Role of NHE-1 in estrogen-induced hypertrophy. J Mol Cell Cardiol 46: 360-369, 2009.

43. Ciccarelli M, Cipolletta E, Santulli G, Campanile A, Pumiglia K, Cervero P, Pastore L, Astone D, Trimarco B and Iaccarino G: Endothelial beta2 adrenergic signaling to AKT: Role of Gi and SRC. Cell Signal 19: 1949-1955, 2007.

44. Ferro A, Queen LR, Priest RM, Xu B, Ritter JM, Poston L and Ward JP: Activation of nitric oxide synthase by beta 2 -adrenoceptors in human umbilical vein endothelium in vitro. Br J Pharmacol 126: 1872-1880, 1999.

45. Grossini E, Caimmi P, Molinari C, Uberti F, Mary D and Vacca G: CCK receptors-related signaling involved in nitric oxide production caused by gastrin 17 in porcine coronary endothelial cells. Mol Cell Endocrinol 350: 20-30, 2012. 
46. Alderton WK, Cooper CE and Knowles RG: Nitric oxide synthases: Structure, function and inhibition. Biochem J 357: 593-615, 2001.

47. Bhutto IA, Baba T, Merges C, McLeod DS and Lutty GA: Low nitric oxide synthases (NOSs) in eyes with age-related macular degeneration (AMD). Exp Eye Res 90: 155-167, 2010.

48. Liaudet L, Soriano FG and Szabó C: Biology of nitric oxide signaling. Crit Care Med 28 (Suppl 4): N37-N52, 2000.

49. Ma L, Chen S, Li L, Deng L, Li Y and Li H: Effect of allicin against ischemia/hypoxia-induced $\mathrm{H} 9 \mathrm{C} 2$ myoblast apoptosis via eNOS/NO pathway-mediated antioxidant activity. Evid Based Complement Alternat Med 2018: 3207973, 2018.

50. Franceschelli S, Pesce M, Ferrone A, Gatta DM, Patruno A, Lutiis MA, Quiles JL, Grilli A, Felaco M and Speranza L: Biological effect of Licochalcone $\mathrm{C}$ on the regulation of $\mathrm{PI} 3 \mathrm{~K} / \mathrm{Akt} / \mathrm{eNOS}$ and $\mathrm{Nf}-\kappa \mathrm{b} / \mathrm{iNOS} / \mathrm{NO}$ signaling pathways in $\mathrm{H} 9 \mathrm{C} 2$ cells in response to LPS stimulation. Int J Mol Sci 18 : E690, 2017.

51. Zuo YH, Han QB, Dong GT, Yue RQ, Ren XC, Liu JX, Liu L, Luo $\mathrm{P}$ and Zhou H: Panax ginseng polysaccharide protected H9c2 cardiomyocyte from hypoxia/reoxygenation injury through regulating mitochondrial metabolism and RISK pathway. Front Physiol 9: 699, 2018

52. Zaobornyj T and Ghafourifar P: Strategic localization of heart mitochondrial NOS: A review of the evidence. Am J Physiol Heart Circ Physiol 303: H1283-H1293, 2012.

53. Celojevic D, Petersen A, Karlsson JO, Behndig A and Zetterberg M: Effects of $17 \beta$-estradiol on proliferation, cell viability and intracellular redox status in native human lens epithelial cells. Mol Vis 17: 1987-1996, 2011.

54. Chetty CS, Vemuri MC, Reddy GR and Suresh C: Protective effect of 17-beta-estradiol in human neurocellular models of lead exposure. Neurotoxicology 28: 396-401, 2007.

55. Sandoval M, Cutini P, Rauschemberger M and Massheimer V: The soyabean isoflavone genistein modulates endothelial cell behavior. Br J Nutr 104: 171-179, 2010.
56. Uttara B, Singh AV,Zamboni P and Mahajan RT: Oxidative stress and neurodegenerative diseases: A review of upstream and downstream antioxidant therapeutic options. Curr Neuropharmacol 7: 65-74, 2009.

57. Yu HL, Zhang XH, Xiao R, Li L, Xiang L, Feng JF, Yuan LH and Ma WW: Effects of genistein and folic acid on neuronal membrane and mitochondrial membrane damaged by $\beta$-amyloid peptides 31-35. Zhonghua Yu Fang Yi Xue Za Zhi 44: 607-611, 2010 (In Chinese).

58. Borrás C, Gambini J, López-Grueso R, Pallardó FV and Viña J: Direct antioxidant and protective effect of estradiol on isolated mitochondria. Biochim Biophys Acta 1802: 205-211, 2010.

59. Richardson TE, Yu AE, Wen Y, Yang SH and Simpkins JW: Estrogen prevents oxidative damage to the mitochondria in Friedreich's ataxia skin fibroblasts. PLoS One 7: e34600, 2012.

60. Asokan Shibu M, Kuo WW, Kuo CH, Day CH, Shen CY, Chung LC, Lai CH, Pan LF, Vijaya Padma V and Huang CY: Potential phytoestrogen alternatives exert cardio-protective mechanisms via estrogen receptors. Biomedicine (Taipei) 7: 11, 2017.

61. Patten RD, Pourati I, Aronovitz MJ, Baur J, Celestin F, Chen X, Michael A, Haq S, Nuedling S, Grohe C, et al: 17beta-estradiol reduces cardiomyocyte apoptosis in vivo and in vitro via activation of phospho-inositide-3 kinase/Akt signaling. Circ Res 95: 692-699, 2004.

62. Feldman RD and Limbird LE: GPER (GPR30): A nongenomic receptor (GPCR) for steroid hormones with implications for cardiovascular disease and cancer. Annu Rev Pharmacol Toxicol 57: 567-584, 2017.

63. Prossnitz ER and Barton M: The G protein-coupled estrogen receptor GPER in health and disease. Nat Rev Endocrinol 7: 715-726, 2011. 